Johannes Kabatek, University of Zürich

\title{
Introduction: On invisible hands, visible speakers, and "language dynamics”
}

\section{The final cause of this special issue}

The reason (just to avoid the word cause), or better: the final cause for the emergence of this special issue is the following: after releasing four issues, the online journal Energeia had developed quite well and had been received quite positively; however, it was very much concentrated on the personal work of Eugenio Coseriu and its reception was basically limited to a more or less reduced circle of people interested particularly in his concrete oeuvre. This was understandable because the journal came out of the Coseriu Archives and one of the goals of the "documentation" section was to make part of the unpublished material of the archives accessible. However, the overall aim was rather to carry on fundamental questions of linguistic thought and to consider Energeia as a discussion platform for current linguistic problems, not as a place for a somehow nostalgic record of Coserius's wisdom as opposed to the "lost pathways" of contemporary linguistics. So I thought about how to open the journal to a more general public and how to integrate people from outside the circle of Coserians. The idea came up to propose a general subject and to ask for contributions to a fundamental epistemological question. This was at the same time a very Coserian approach since Coseriu always insisted on the importance of a critical self-reflection of science and the necessity of trying to find out what we are really doing, where we are, and whether our methods are adequate for our object or not.

Talking about these plans for the future of Energeia to a colleague (Gabriele Diewald) ${ }^{1}$ at the beginning of 2013, she said that she could imagine the question of causality and finality to be an interesting one for such a general discussion, and I immediately picked up this idea because it seemed to me to be the perfect subject for a discussion:

- It was an actual question since the old dream of causal "explanations" of linguistic phenomena, which has been present in linguistics at least since the Neogrammarians, had again become increasingly important in recent times. New experimental and quantitative techniques seem to be bringing us closer to how language works and how language dynamics can be explained.

- It was a fundamental epistemological question.

- It was also one of Coseriu's basic concerns from his early work onwards to remember the Aristotelian distinction of causes and to claim that the speaker's activity is goal-oriented. In his view, this is where the question of language dynamics has to be posed.

In March 2013, a call for papers was posted in different linguistic forums in the Internet. It contained the following assumptions: ${ }^{2}$

Many thanks to Gabriele Diewald for this excellent idea!

I would like to thank Klaas Willems for some very helpful comments on a previous version of the call. 
One of the central aims of contemporary linguistics is to find causal explanations of linguistic activity (language use) and language change. The two major arguments advanced in this context are the following:

- linguistic research has finally - theoretically, experimentally and quantitatively achieved a methodological and theoretical state that allows linguists to provide causal explanations;

- linguistics is finally able to apply - both theoretically and methodologically - the standards and criteria that have long been generally accepted in the sciences (above all in the natural sciences, but also in the social sciences).

Does this mean that the criticism of causal explanations of language change (and, in a wider sense, of linguistic activity in general) levelled by Coseriu as early as 1958 has now finally been overcome and has altogether lost its importance? Coseriu states: “The very idea of 'causality' in the so-called 'evolution' of language is a residue of the old conception of languages considered as 'natural organisms' as well as of the positivistic dream to discover the 'laws' of human speech (or languages) and to transform linguistics into a 'science of laws' analogous to physics." (Coseriu 1958, 101, our translation).

Coseriu draws on the classical, Aristotelian distinction of four different kinds of causes. He claims that the dynamics of language use and language change can only be properly understood in terms of finality, i.e. if the object of linguistic research is conceived as an intentional phenomenon in the Aristotelian sense of a "causa finalis": as a product of individual, free, goal-oriented action (enérgeia), subordinating the other causalities to the final cause. According to Coseriu, the telos, the goal of linguistic activity, is not (at least not in general) the modification of a language but, quite simply, successful communication.

This is what Rudi Keller tried to separate in his theory of "the invisible hand" in language change. On the one hand, Keller stated that pure causal theories are not adequate to explain language change and that from the viewpoint of the individual engaged in communication only finality is at stake. On the other hand, on the level of language, Keller claims that change is the "causal consequence" of the sum of intentional individual actions. The question that arises is whether this "causal consequence" is really something else than the individual's finality and whether it makes sense to look at change independently from the speaker's linguistic activity - in the sense of general "laws of change", be they culturally or even physically determined. Moreover, can it be the purpose of research into the dynamics of language use and language change to explain causality or even to predict language evolution?

These and similar questions arise with respect to phonology, morphology, semantics, syntax, and pragmatics, thus bearing on the theory of language in general. The idea of the discussion forum is not to propose a strict format or limitation of any sort, but to invite interested scholars to participate in the discussion with any kind of relevant contribution, be it a short statement, a discussion note with a few arguments, or an elaborate article. All contributors will have access to all contributions prior to publication; they will be given the opportunity to add comments to statements of other scholars so that in the end not only the original points of view, but also the outcome of a whole discussion process will be published. 
After posting the call, the original plan was to publish the whole issue in October 2013, but, for several reasons, it took until the beginning of 2014 to finish the edition. The result can be considered to be an enormous success on the one hand, and a failure on the other. The success consists in the 24 contributions published here, with almost 200 pages having about the extension of a book and containing very astute contributions on the issue, even some extensive studies, and a real discussion with pros and cons, comments, and replies. The failure consists in the fact that, apart from a lively discussion on details, all the authors more or less coincide in their general view on the need for a finalistic view on language activity and that it was impossible to get a clear statement of what we could call, for lack of a better term, a "causality hardliner": in almost all the contributions, there is not even a slight claim for the possibility of at least some causal explanation in linguistics. So the discussion lacks opponents, and this makes it to a certain degree incomplete. But the opponents are there, be they imagined or concrete. They are identifiable in publications and in the discourse of the last years.

In the following section, I will very briefly present the contributions to this issue. The third and fourth section of this introduction will be dedicated to some general reflections on finality and language.

\section{A lively discussion}

The issue raised by the call for papers was addressed by the different authors, on the side of form and of content, in various manners. Some contributions are just short statements, others are exhaustive articles. Some referred explicitly to the Aristotelian distinctions of causes, others rather focused on related questions: explanation, evolution, time, frequency, expressivity, language change, the relationship between language and discourse, etc... There are seven main contributions and 18 comments and replies. Since a thematic ordering was difficult due to the complex interrelation of statements and responses, we arbitrarily decided to order the texts alphabetically, with comments and replies following each larger contribution.

The first contribution is by Göran Hammarström (Monash University, Australia), the most active of all participants, who not only sent a statement but also commented on all the other contributions, sometimes provoking interesting reactions. In his remarks on Esa Itkonen's contribution, Hammarström explains the trajectory of his own life, when he was surrounded, in the middle of the $20^{\text {th }}$ century, by linguists with a historical, partly even still neogrammarian orientation. Hammarström at that moment received with applause the publication of Coseriu's Sincronía, diacronía e historia and was one of the first to write a review of this book. ${ }^{3}$ He stresses the fact that, from his point of view, the question of causality and intentionality has been resolved for a long time and that language change as a result of free will is "intended, not caused". He insists, however, on the fact that his observations particularly refer to diachrony and to spoken language. This is questioned in a comment by myself, when I defend the necessity of considering the difference between synchrony and diachrony as a pure methodological and, even with this limitation, a misleading one.

See Hammarström 1959. In Kabatek/Murguía 1997, 93, Coseriu mentions the contact to Hammarström, who invited him to Stockholm and Uppsala after the International Congress of Linguistics in Copenhagen in 1957, a crucial moment in Coseriu's life when he first participated in a meeting in Europe after the publication of some of his most important contributions of the early $1950 \mathrm{~s}$. 
Hammarström in change insists in the Saussurean distinction in his response and criticizes the confusion of linguists who look at texts in a diachronic sense. ${ }^{4}$

In a very intensive and complex, but at the same time very clear contribution, Esa Itkonen (University of Turku, Finland) shows how different approaches argue in order to explain linguistic facts. He departs from a logical, formal system that allows him to analyse the different partial processes and intentionalities that are metonymically simplified when we talk of "cause". This formal system allows him to distinguish the argumentation of different types of explanation: what he calls the rational, the functional, the evolutionary, the deterministic, the pseudo-deterministic, the statistical, the coherentist explanation, and finally, the conceptual analysis or explication.

Christinel Munteanu (University of Piteşti, Romania) insists in Eugenio Coseriu's view on language as a cultural object and the necessity of explaining language activity in terms of a "final cause". He offers some background information about the philosophers Coseriu's thought is based on, from the Aristotelian fundament and the reference to German idealism ${ }^{5}$ until the philosophy of the $20^{\text {th }}$ century, with some remarks on the Romanian linguist Hasdeu, who defended language as a cultural object at the end of the $19^{\text {th }}$ century. An interesting discussion in the follow-up of Munteanu's paper, with contributions by Göran Hammarström and Javier de la Higuera (University of Granada) challenges the question of the relationship between linguistics and philosophy.

Emma Tămâianu-Morita (Akita University, Japan) discusses the notion of "expressive knowledge", the linguistic knowledge speakers have to construct a text or discourse, in Coserian terms. She shows, with the help of a translation experiment, the ability of speakers to reflect on their communicative goals and how this ability is employed in a concrete setting. The experiment serves her as a starting point for a more general reflection on expressivity and language change.

Dumitru Cornel Vîlcu (University of Cluj-Napoca, Romania) focuses on the relationship between causality and time. He insists in the importance of Coseriu's reflections on language and time and relates the Aristotelian distinctions on causes to different time dimensions. The notion of "time" and historicity is discussed with reference to a series of philosophers, with insistence on the non-agentivity of time and the creativity of the individual as source for language dynamics.

Klaas Willems (Ghent University, Belgium) addresses the issue of frequency and quantitative analysis and asks if frequency can be regarded as an "explanatory causal concept". This is a central issue in the context of the whole discussion on causal and final explanations since it is particularly in quantitative linguistics where the possibility of causal explanations is claimed. Willems shows by means of some German examples (syntactic changes in the case of the verb aufsetzen) how frequency data can be usefully employed and combined with other types of data in order to better describe dynamic processes (without, however, "explaining" them causally).

Finally, Esme Winter-Froemel (University of Tübingen, Germany) goes into the question of language change from several viewpoints; she discusses "causal" explanations like Keller's

4 Maybe a clearer distinction of different concepts of historicity could be helpful here: Hammarström's statement that a text can only be synchronic is right in several senses, but it is also wrong in the way that a language is a historical object and that texts can also refer to previously uttered texts and be part of discourse traditions, see Kabatek 2005a.

5 It would be important to also mention Herder, the "father" of the German idealist school and the first to clearly insist on the linguistic "liberation" of humans with regards to nature. 
"Theory of the invisible hand" (see also below) or the S-curve paradigm (defended, among others, by William Croft) as well as "final" explanations (Coseriu), identifying advantages and disadvantages of both approaches and stressing on the potential of a usage-based view that shows how the dynamics of language is grounded "on the level of the individual speakers and their utterances".

All these contributions have been commented upon by other authors, and in some cases there has even been a debate with several replies: a real, lively discussion on some central issues related to the question of intentionality and causality in linguistics.

\section{A word on the "invisible hand"}

One of the most frequently cited notions in several of the contributions is the famous "invisible hand". We already evoked it in the call for papers, and for good reasons: when linguists debate on the "invisible hand", the separation of views becomes manifest. Since Rudi Keller's introduction of the "theory of the invisible hand" into modern linguistics ${ }^{6}$, the old idea by Adam Smith that certain social or economic processes seem to obey laws that are independent of the intention of their agents (as if an invisible hand guided them) has become almost a standard topic in linguistics. Some linguists repeat it as if it was the generally accepted explanation of language change, and it is frequently cited in the context of evolutionary linguistics and recent quantitative approaches. ${ }^{7}$ Keller's claim is that language change is a causal phenomenon, and he explicitly opposes his view to Coseriu's statements on finality presented in Sincronía, diacronía e historia in the 1950s. Keller's argumentative strategy consists in offering a synthesis between causal and final explanations and then in subsuming individual finality to causality on a higher level. This ends up leaving individual finality in the background and accepting the higher level causality as the "real" place of linguistic dynamics. This abstract level is, according to Keller, not relevant for the individuals when they speak, but it is central for linguistic research. It is where linguists identify the paths and the clines of language dynamics. Speakers, he claims, have neither an awareness of this level nor the will to change languages.

There are many linguists who consider Keller's theory to be part of the contemporary standard view. Hence, the argument that the idea of causal explanations "was long ago given up" (Hammarström) cannot be considered as being unanimously accepted. At the same time, it is neither enough to reject this idea just because in former times linguists had given it up, nor to say - even if it might be true - that there is no "invisible hand" since changes are intentional: this would be as if we said there is a traffic jam because drivers were free to decide what to do. It seems to me neither enough to rely on results or decisions of former times $^{8}$ nor to state axiomatically that language change is simply intentional. But which arguments do we have against the theory of the invisible hand? Isn't it extremely convincing to identify an underlying principle of human action, a cause of the collective results of our individual behaviour? The traffic jam, the path on the grass, black Fridays on the stock market, and grammaticalization - what else are they than results of an invisible hand that led

See Keller 1984, 1990 and the critical remarks in Kabatek 2005b.

See, e.g. Fitch 2007.

This is comparable to the case of the question of the origin of language: the well-known decision of the Société linguistique de Paris against research on this question is obviously not a sufficient argument for rejecting evolutionary linguistics of recent times, where this question again has become a central topic even if the fundamental reason for the rejection might still be the same. 
to something no single individual ever intended but paradoxically provoked? If we look at certain "tendencies" in language change, isn't it obvious that there are at least probabilities of the "invisible hand" guiding the behaviour of individuals into a certain direction and not into another? Is it not true that future tense markers will probably rather evolve out of movement verbs or modals than out of determiners, and that final, unstressed vowels are more likely to be apocopated than to be reinforced? Can't we say that humans are more likely to decide in a certain way than in another, and that this likelihood can be considered - at least statistically as the "cause" of their behaviour?

At this point, I think it is very important to insist on a very fundamental and traditional distinction: the distinction between language and discourse or text. ${ }^{9}$ Even in Rudi Keller's "theory" of the invisible hand, there is no doubt that the speaking activity of the individual is goal-oriented and that there is but intentionality on the level of the individual. What is claimed in Keller's view is that the speaker does not want to change the language but only to communicate efficiently, as the driver only wants to get to his destination as fast as possible, and the broker wants to earn money selling or buying shares. Things are more complicated in reality since the possibility of conscious intervention obviously exists in all of these cases, and the will to change the language is one of the manifold possible intentions of speaking (we can show this e.g. in the case of "politically correct" forms used as a consequence of conscious intervention by the speakers). But this is not the relevant question here: the problem consists in postulating a kind of "abstract agent" on the abstract level. This abstract agent, the "invisible hand", simply does not exist, and to conduct research on something inexistent is absurd. ${ }^{10}$ In my opinion - and in the view of most of the contributors to this discussion forum - an adequate view on language dynamics (or simply on language) will end up leaving causality in the background and accepting the individual finality as the "real" level of linguistic dynamics, the one where individuals - the only real agents - are at work and from where linguistic research must also depart. The consequence of this claim is that we can only postulate that everything that looks like an invisible hand must in fact - and this is so obvious! - be due to the activity of individuals. Once we reach this point, we will have to acknowledge that the action of the individual is not just "free will" in a naive sense. The "free will" of the driver wants to reach the destination as soon as possible, of course. But there is also "free will" when the driver touches the brake fearing that the distance to other cars might be too short. There is not just one simple goal when we speak: we want to communicate efficiently, and sometimes this makes us use complex constructions since these constructions seem to be corresponding better to our needs; and we want to save energy and to pronounce as few sounds as possible and at the same time to be as clear as possible for our interlocutor. All the diverging forces that are responsible for what we call language dynamics must be located at the level of individual intentionality in the end.

The metaphor of the invisible hand might be a very tempting one. But it is also a dangerous one since it makes people believe that there are phantoms at work on the abstract level. The rhetoric strategy that makes Rudi Keller subsume finality to causality must be

9 We should even distinguish language more clearly as a general faculty of humans, language as a particular language system, and concrete speech utterances (see Coseriu 1985).

10 It might not be that absurd in the case of he stock market: here, analysts look at the curves of evolution of the share values and interpret the future evolution according to the shape of the curve. This is also problematic since the curve only very indirectly indicates how the company behind the share is doing; however, the curve is an indirect indicator of the company's state and, what is more important in that case, stock brokers always act after looking at curves. This makes the curve itself become a relevant factor for the behaviour of the agents. In language, similar phenomena are very unlikely to be found. 
clearly identified and, with respect to the "real object of linguistics" (Munteanu), inverted: everything that looks causally motivated by some abstract agent must, in the end, be found in the motivation of the speaker.

\section{Evolution}

If what has been said in the previous section is true, it must basically hold for any causal explanation of language dynamics. In her paper, Esme Winter-Froemel discusses the s-curveparadigm, which is the idea that innovations and changes emerge and spread and generalize like s-curves. There are several examples where corpus studies have shown that s-curve-like evolutions of linguistic facts exist, and they are a central argument for those linguists who in the last years newly evoke the evolution-metaphor in order to explain linguistic dynamics. ${ }^{11}$ Thus, the evolution metaphor is back in linguistics, be it in studies on short-term tendencies, or in studies on the overall history of human languages. As Winter-Froemel convincingly shows, s-curves in language evolution are phenomena that can only be identified ex post and thus do not serve as causal explanations with predictive value. But maybe there is even more: if there are s-curves in language evolution and if they correspond to a typical, general tendency, we cannot ignore this and there might even be - in the sense of a statistic probability - a certain predictive value.

However, there are numerous arguments that justify to be sceptic about the evolutionary paradigm: first, s-curve-shaped evolutions are far from general, and if we look closer at the history of our languages, they don't even seem to indicate a very general tendency. Second, the comparison between the genetic and the linguistic evolution is simply wrong: genes are just surface phenomena, there is nothing but a sequence of chemical substances. By contrast, what we look at in historical corpora are utterances, texts, not language: we have only an indirect, casual access to the language competence of the human brains in the past. We find casual collections of texts and not the history of a language, and we find historical ups and downs and no linear evolutions. Maybe these ups and downs are due to our bad data and better s-curves would become visible with other data, but still we would be on the level of the measurement of texts. So, in a way, the "representativity" of corpus data for a language is a myth (see Kabatek 2013), since it falls into the trap of evolutionary language theories that make the difference between language and text/discourse collapse. Language is not just utterance-reproduction, it is also a strategic activity, and utterances do not all have the same weight on the market. If we think of certain taboo forms, we know that they might be uttered very scarcely. Yet, they are not likely to disappear only due to their low frequency (see our comment on Willems).

There is, however, something we should consider seriously: there are of course patterns of human behaviour that show regularity. Even if we claim the existence of free will, as historians, we know that certain constellations between individuals and groups will more likely lead to a particular action than to another one. This is also true for language dynamics: individuals have free will and they use their individual creativity when they speak. What we

11 There is a long list of authors and works published in the last years who again claim the parallelism between biological and linguistic evolution (see Croft 2000, 2008, among others). We cannot go into the long history of this metaphor in linguistics and the back-and-forth-movement between linguistics and other disciplines going at least, for modern evolutionary thought, back to Darwin, who also referred to language as a comparable case to biological evolution when he claims (1871, I, 59): "The formation of different languages and of distinct species, and the proofs that both have been developed through a gradual process, are curiously the same."). 
can describe as probabilities of human behaviour is somehow part of this individual behaviour: there are scenarios at each stage of the s-curve that can show why or for which communicative purpose an individual uses a form which from a distant perspective is interpreted to be the "emergent" in contrast to "the old" form. But the deciding instance is always the "visible" hand of the individual: her or his speaking activity.

\section{Language dynamics: a tautology}

With all this in mind, it may be convincing to come back to Coseriu's 1988 dictum about the inexistence of language change: Language change does not exist in the sense that there is a stable language that changes from a stable state A to a stable state B, nor is there any "tendency" of systems to search for stability. System harmony in a structuralist sense must be explained as a tendency of speakers towards more or less symmetric organizations of vowel and consonant systems, not as a tendency of the system itself, ${ }^{12}$ grammaticalization paths are paths speakers go along by their activity, with all the "typological tendencies" being speaker's tendencies (generally related with cognitive, articulatory, and perceptive principles). This also means that a difference between research on language as a stable system and research on language dynamics (Schuchardt already said it clearly!) is but a methodological one, and it should even be abandoned in methodology because it is deeply misleading. "Language dynamics" is thus a tautological expression since it could be interpreted as being opposed to "stable" language: there is but dynamic language activity. In that sense, most of the authors who participate in this discussion forum basically agree on the adequacy of final/intentional explanations. This could be considered as a "solution" of the problem exposed in the call for papers in a certain direction, but it is by no means representative of today's linguistics. Now, it shows that there are linguists with different backgrounds and with different orientation who basically agree on the importance of insisting - against all recent prophecies that linguistic explanations can finally be causal - in the fact that language activity is still, also in the $21^{\text {st }}$ century, the same old Aristotelian-Humboldtian, goal-oriented, dynamic Energeia it used to be since humans were humans.

12 This obviously does not mean that the explicit goal of the speakers is to create a symmetric system. But there seems to be an articulatory and cognitive tendency towards the systematic organization of relevant sounds: when a certain degree of opening is used for a front vowel, an articulatory space is also opened for a corresponding back vowel and vice-versa 


\section{References}

Aristotle, Metaphysics, transl. W. D. Ross, http://classics.mit.edu/Aristotle/metaphysics.html

Coseriu, Eugenio (1958), Sincronía, diacronía e historia, Montevideo. (German translation: Synchronie, Diachronie und Geschichte. Das Problem des Sprachwandels, München: Wilhelm Fink 1974.)

Coseriu, Eugenio (1985): "Linguistic Competence: What is it Really?", The Presidential Address of the Modern Humanities Research Association, The Modern Language Review, vol. 80, part 4, XXV-XXXV.

Coseriu, Eugenio (1988), "Linguistic change does not exist", in: Energeia und Ergon. Sprachliche Variation - Sprachgeschichte - Sprachtypologie. Studia in honorem Eugenio Coseriu, Band I: Schriften von Eugenio Coseriu, herausgegeben von Jörn Albrecht, Jens Lüdtke und Harald Thun, Tübingen: Gunter Narr, 147-157.

Croft, William (2000): Explaining language change: an evolutionary approach. Harlow, Essex: Longman.

Croft, William (2008): "Evolutionary linguistics", Annual Review of Anthropology 37, 219234.

Darwin, Charles (1871): The descent of man, and selection in relation to sex, 2 vols., London: John Murray.

Dennett, Daniel C. (1987), The intentional stance, Cambridge, Massachusetts: The MIT Press.

Falcon, Andrea (2012): “Aristotle on Causality", The Stanford Encyclopedia of Philosophy (Winter 2012 Edition), Edward N. Zalta (ed.), URL = http://plato.stanford.edu/archives/win2012/entries/aristotle-causality/

Fitch, W. Tecumseh (2007): "Linguistics: An invisible hand", Nature 449, 665-667.

Hammarström, Göran (1959): Review of E. Coseriu, Sincronía, Diacronía e Historia, in: Le Maître Phonétique 112, 58-65.

Itkonen, Esa (2003): What is Language? A Study in the Philosophy of Linguistics. Turku: Turun yliopisto (Publications in General Linguistics 8).

Itkonen, Esa (2011): “On Coseriu's legacy”, Energeia 3, 1-29.

Kabatek, Johannes (2005a): “A propos de l'historicité des textes”, in: A. Murguía (ed.): Sens et références. Mélanges Georges Kleiber, Tübingen: Narr.

Kabatek, Johannes (2005b): "Über Trampelpfade, sichtbare Hände und Sprachwandelprozesse", in: Thomas Stehl (ed.): Unsichtbare Hand und Sprecherwahl. Typologie und Prozesse des Sprachwandels in der Romania, Tübingen: Narr.

Kabatek, Johannes (2013): “¿Es posible una lingüística histórica basada en un corpus representativo?", Iberoromania 77, 8-28.

Kabatek, Johannes / Murguía, Adolfo (1997): „Die Sachen sagen, wie sie sind...“. Eugenio Coseriu im Gespräch, Tübingen: Narr.

Keller, Rudi (1984): "Bemerkungen zur Theorie des sprachlichen Wandels", in: Zeitschrift für Germanistische Linguistik 12, 63-81.

Keller, Rudi (1994): Sprachwandel. Von der unsichtbaren Hand in der Sprache, 2nd ed. (1st ed. 1990), Tübingen: Francke; English translation: On Language Change: The Invisible Hand in Language, Abingdon: Routledge, 2004.

Ohala, John (1983): “Cross-language use of pitch: an ethological view”, Phonetica 40, 1-18. 